\title{
The class II major histocompatibility complex molecule BoLA-DR is expressed by endothelial cells of the bovine corpus luteum
}

\author{
Matthew J Cannon ${ }^{1,3}$, John S Davis ${ }^{2,3}$ and Joy L Pate ${ }^{1,3}$ \\ ${ }^{1}$ Department of Animal Sciences, The Ohio State University/Ohio Agricultural Research and Development Center, \\ 1680 Madison Avenue, Wooster, Ohio 44691, USA, ${ }^{2}$ Department of Obstetrics and Gynecology, Olson Center for \\ Women's Health, University of Nebraska Medical Center, Omaha, Nebraska 68198, USA and ${ }^{3}$ Omaha VA Medical \\ Center, Omaha, Nebraska 68105, USA
}

Correspondence should be addressed to J L Pate; Email: pate.1@osu.edu

M J Cannon is now at Animal Sciences Department, Oregon State University, Corvallis, Oregon 97331, USA

\begin{abstract}
Cells expressing class II major histocompatibility complex (MHC) molecules are found within the corpus luteum (CL) of several species. Expression and localization of class II MHC molecules in the bovine CL were examined in the present study.

Immunohistochemical evaluation revealed class II MHC molecules on single cells in early CL (days 4 and 5 post-estrus). Two class II MHC-expressing cell types were observed in midcycle CL (days 10-12 post-estrus), single cells similar to those observed in the early CL, and endothelial cells. Not all endothelial cells expressed class II MHC, and further investigation revealed expression of only one type of class II MHC molecule, DR, on endothelial cells. Class II MHC was also localized to endothelial cells in late CL (day 18 post-estrus). Steroidogenic luteal cells were negative for class II MHC throughout the estrous cycle. Quantitative RT-PCR revealed higher $(P<0.05)$ concentrations of mRNA encoding the $\alpha$-subunit of DR (DRA) in late CL when compared with those in the early CL. DRA mRNA abundance was also measured in cultures of mixed luteal and luteal endothelial (CLENDO) cells, in the presence or absence of tumor necrosis factor- $\alpha$ (TNF). No differences were found in the DRA mRNA concentration between mixed luteal and CLENDO cell cultures, and TNF had no effect on DRA mRNA concentration in both cell types. Expression of DR by endothelial cells of the midcycle CL may induce anergy of T lymphocytes, or stimulate them to secrete products that enhance normal luteal function.
\end{abstract}

Reproduction (2007) 133 991-1003

\section{Introduction}

Evidence supporting the role of immune cells in the regulation of luteal function is accumulating. Macrophages and $\mathrm{T}$ lymphocytes have been detected in the corpus luteum $(\mathrm{CL})$ of several species in numbers that vary with stage or functional state of the CL (Bagavandoss et al. 1990, Bränström et al. 1994, Lawler et al. 1999, Penny et al. 1999, Krusche et al. 2002, Nagaosa et al. 2002, Townson et al. 2002, Komatsu et al. 2003, Neuvians et al. 2004). The presence of mRNAs encoding various cytokines and the corresponding proteins has also been demonstrated in luteal tissue (Telleria et al. 1998, Penny et al. 1999, Petroff et al. 1999, Sakumoto et al. 2000, 2006, Krusche et al. 2002, Townson et al. 2002, Komatsu et al. 2003, Neuvians et al. 2004, Nishimura et al. 2004) T-cell cytokines such as interleukin-1 $\beta$ (IL1B), IL6, tumor necrosis factor- $\alpha$ (TNF), and interferon- $\gamma$ (IFNG) modulate the synthesis of progesterones and prostaglandins by granulosal, thecal, and luteal cells in vitro (Nothnick \& Pate 1990, Fairchild \& Pate 1991, Benyo \& Pate 1992, Gorospe et al. 1992, Alpizar \& Spicer 1994, Townson \& Pate 1994, 1996, Del Vecchio \& Sutherland 1997, Young et al. 1997, Breard et al. 1998). Collectively, these observations suggest the potential for infiltrating immune cells to be activated within luteal tissue, and the cytokines they produce to modulate luteal function.

The activation of T lymphocytes occurs via a receptorligand type interaction between the T-cell receptor for antigen and major histocompatibility complex (MHC) molecules on the surface of cells stimulating T-cell activation (Altman et al. 1990). Two distinct types of 
MHC molecules, class I and class II MHC molecules, are involved in the activation of $\mathrm{T}$ lymphocytes. Class I MHC molecules are found on all nucleated cell types, with several notable exceptions. These molecules bind with intracellularly generated peptide fragments, and the presence of complexes of peptide-class I MHC at the cell surface allows cells to interact with $\mathrm{CD} 8^{+}$ (cytotoxic) T lymphocytes (Groothuis et al. 2005). This interaction forms the basis for immune system surveillance of somatic cells for the presence of viral proteins or aberrantly synthesized endogenous proteins (Fruh et al. 1997, Cresswell et al. 2005, Rock \& Shen 2005). Class II MHC molecules also bind with peptide fragments, but expression of class II MHC molecules is more restricted. Class II MHC molecules allow interaction of cells with $\mathrm{CD}^{+}{ }^{+}$(helper) $\mathrm{T}$ cells, and, classically, class II MHC expression by the so-called professional antigen-presenting cells of the immune system (macrophages, dendritic cells, and B lymphocytes) has been regarded to be of greatest significance, due to the necessity of these molecules for proper immune system function (Scholl \& Geha 1994, Grusby \& Glimcher 1995, Rohn et al. 1996). However, class II MHC expression is not limited to these cells, and it has become apparent that expression under normal physiological as well as pathological conditions significantly impacts the function of various tissues (Knolle \& Limmer 2001, Pober et al. 2001, Kelly et al. 2003). Finally, three types of class II MHC molecules, referred to as DP, DQ, and DR, are expressed on professional antigen-presenting cells.

Expression of class II MHC molecules by the cells of the CL has been demonstrated in several studies (Khoury \& Marshall 1990, Benyo et al. 1991, Kenny et al. 1991, Bukovský et al. 1995, Bowen \& Keyes 1999, 2000, Lawler et al. 1999, Penny et al. 1999, Lehman et al. 2000, Hoffmann et al. 2004). Macrophages would certainly account for a percentage of the class II-positive cells in the $\mathrm{CL}$, but expression of class II MHC by cells other than macrophages has been convincingly demonstrated (Khoury \& Marshall 1990, Benyo et al. 1991, Kenny et al. 1991, Bukovský et al. 1995, Lehman et al. 2000, Hoffmann et al. 2004). In the bovine CL, expression of class II MHC has been demonstrated in several studies (Benyo et al. 1991, Penny et al. 1999, Lehman et al. 2000), but data are lacking on the convincing demonstration of the identity of class II MHC-expressing cells in the bovine CL. The present study was undertaken to identify the cell type(s) in the bovine $\mathrm{CL}$ that expresses class II MHC, since identification of these cells is crucial to understanding the role of the immune system in the regulation of luteal function. The overall hypothesis is that cells in addition to macrophages express class II MHC in the bovine $\mathrm{CL}$, and that expression of class II MHC on these cells changes with the functional status of the $\mathrm{CL}$.

\section{Materials and Methods}

\section{Reagents}

Powdered Hams F-12 culture medium, gentamicin, fetal bovine serum, SuperScript II Reverse Transcriptase, and TRIzol reagent were purchased from Invitrogen. Recombinant RNasin and dNTPs were purchased from Promega. Random hexamer primers were acquired from Amersham Pharmacia Biotech. Oligonucleotide primers were obtained from Operon (Huntsville, $A L$, USA). DyNAmo HS SYBR Green qPCR kits were purchased from MJ Research (Waltham, MA, USA). Fluorescein-labeled Griffonia (Bandeiraea) simplicifolia lectin-1 (FITC-BS-1), non-specific mouse IgG, normal horse serum, and histological grade BSA were purchased from Vector Laboratories (Burlingame, CA, USA). Nonimmune rabbit serum, 4',6-diamidino-2-phenylindole (DAPI), BSA (fraction V), and HEPES were acquired from Sigma Chemical Company. Type I collagenase was purchased from Worthington Biochemical Corp. (Freehold, NJ, USA). Bovine luteinizing hormone (LH; AFP II 743B) was provided by the National Hormone and Peptide Program and AF Parlow (Torrence, CA, MD, USA). Insulin-transferrin-selenium (ITS) premix was obtained from Collaborative Research Products. Antibovine class II MHC monoclonal antibodies (mAbs) and anti-bovine CD172a mAb were purchased from VMRD, Inc. (Pullman, WA, USA). Rabbit anti-rat P450 sidechain cleavage enzyme (CYP11A1) polyclonal antiserum was obtained from Research Diagnostics, Inc. (Concord, MA, USA). Mouse anti-human CD68 mAb was purchased from Dako (Carpinteria, CA, USA). Alexa Fluor 546-conjugated goat anti-mouse $F\left(a^{\prime}\right)_{2}$ fragment and Alexa Fluor 488-conjugated goat anti-rabbit $\mathrm{F}\left(\mathrm{ab}^{\prime}\right)_{2}$ fragments were purchased from Invitrogen. Agarose was acquired from Amresco (Solon, $\mathrm{OH}$, USA). Tissue culture flasks were from Corning (Corning, NY, USA). Unless otherwise specified, all other chemicals, reagents, and supplies were purchased from Sigma Chemical Co. or VWR Scientific Products (West Chester, PA, USA).

\section{Animals and tissue collection}

For all experiments except those involving $\mathrm{CL}$ endothelial (CLENDO) cells, corpora lutea were collected from normally cycling, multiparous, lactating dairy cows between 3 and 6 years of age. Corpora lutea were removed by transvaginal lutectomy on days $4,5,10-12$, or 18 post-estrus (day 0 , day of estrus), and were cut into four equal pieces. Two pieces were snap-frozen in liquid nitrogen and stored at $-80{ }^{\circ} \mathrm{C}$ until RNA was extracted. The remaining pieces were embedded in Tissue-Tek optimal cutting temperature (OCT) medium, frozen in liquid isopentane chilled in liquid nitrogen, and stored at $-80{ }^{\circ} \mathrm{C}$ until frozen sections for immunohistochemistry were prepared. Handling of animals and surgical procedures were carried out in accordance with 
procedures approved by the Institutional Laboratory Animal Care and Use Committee of The Ohio State University.

\section{Immunohistochemistry}

Luteal tissues embedded in OCT were sectioned at a thickness of $7 \mu \mathrm{m}$ on a Leica CM 1850 cryostat (Leica Microsystems, Bannockburn, IL, USA). Tissue sections were mounted on Superfrost Plus slides (Fisher Scientific, Fair Lawn, NJ, USA) and stored at $-20^{\circ} \mathrm{C}$ until use. Prior to use in immunohistochemical procedures, unfixed tissue sections were air dried for $10 \mathrm{~min}$ at $27^{\circ} \mathrm{C}$, then fixed in ice-cold $95 \%$ ethanol for $10 \mathrm{~min}$. After fixation, sections were washed $(3 \times 5 \mathrm{~min}$ in ice-cold $\mathrm{PBS}$ (137 mM NaCl, $8.1 \mathrm{mM} \mathrm{Na}_{2} \mathrm{HPO}_{4}, 1.47 \mathrm{mM} \mathrm{KH} \mathrm{PO}_{4}$, $\left.2.68 \mathrm{mM} \mathrm{KCl}, 0.5 \mathrm{mM} \mathrm{MgCL} \cdot 6 \mathrm{H}_{2} \mathrm{O}, \mathrm{pH} 7.4\right)$ ) and used in immunohistochemical procedures. Immunohistochemical procedures were performed on sections from a minimum of four $\mathrm{CL}$ removed at each time point listed above.

Primary antibodies, their specificity, commercial source, and the working dilutions used in immunohistochemical procedures are listed in Table 1. In the first procedure, steroidogenic luteal cells were identified using rabbit anti-CYP11A1 antiserum in conjunction with Alexa Fluor 488-conjugated goat anti-rabbit $\mathrm{F}\left(\mathrm{ab}^{\prime}\right)_{2}$ fragment as a $2^{\circ} \mathrm{Ab}$ (steroidogenic cells display green fluorescence), and cells expressing class II MHC cell surface antigens were identified using a cocktail of three monoclonal antibovine class II MHC antibodies in conjunction with Alexa Fluor 546-conjugated goat anti-mouse $F\left(a b^{\prime}\right)_{2}$ fragment as a $2^{\circ} \mathrm{Ab}$ (labeled cells display red fluorescence). Following fixation and wash steps, sections were incubated for $30 \mathrm{~min}$ at $27^{\circ} \mathrm{C}$ in PBS containing $1 \%$ histological grade BSA (PBS/BSA) with $10 \%$ normal horse serum. Sections were rinsed $(1 \times$ 3 min with ice-cold PBS) and incubated at $27^{\circ} \mathrm{C}$ for $2 \mathrm{~h}$ with anti-CYP11A1 antiserum diluted in PBS/BSA containing $10 \%$ normal horse serum and $2 \%$ normal bovine serum ( $1^{\circ} \mathrm{Ab}$ diluent). Slides were washed and sections were incubated at $27^{\circ} \mathrm{C}$ for $2 \mathrm{~h}$ with mouse anti-bovine class II MHC mAbs. In parallel, luteal tissue sections were incubated with a cocktail of mouse anti-bovine CD172a and mouse anti-human CD68 mAbs to identify monocytes and macrophages, as described previously (Townson et al. 2002). Slides were washed again and incubated at $27^{\circ} \mathrm{C}$ for 3 min with $2^{\circ}$ Abs diluted 1:200 each in PBS/BSA containing $2 \%$ normal bovine serum $\left(2^{\circ} \mathrm{Ab}\right.$ diluent). Slides were washed again and counterstained with $3 \mu \mathrm{g} / \mathrm{ml}$ DAPI in PBS (nuclei display blue fluorescence). Non-immune rabbit serum and non-specific mouse IgG were substituted for the antiCYP11A1 antiserum (not shown) and mouse antibovine class II MHC mAbs respectively as negative controls to confirm primary antibody specificity.

In the second procedure, endothelial cells were identified using FITC-BS-1 (labeled endothelial cells display green fluorescence), as previously described (Clark et al. 2004), and cells expressing class II MHC cell surface antigens were identified using the same antibodies and dilutions as in the first experiment. Following fixation and wash steps, sections were incubated for $30 \mathrm{~min}$ at $27{ }^{\circ} \mathrm{C}$ with FITC-BS-1 diluted 1:500 in PBS. Slides were then washed, and sections were incubated for $30 \mathrm{~min}$ at $27^{\circ} \mathrm{C}$ in PBS/BSA with $10 \%$ normal horse serum. Slides were then rinsed and sections were incubated at $27^{\circ} \mathrm{C}$ for $2 \mathrm{~h}$ with mouse anti-bovine class II MHC antibodies. Slides were washed again and incubated at $27^{\circ} \mathrm{C}$ for 30 min with $2^{\circ} \mathrm{Ab}$ diluted $1: 200$ in $2^{\circ} \mathrm{Ab}$ diluent. Slides were then washed and counterstained with $3 \mu \mathrm{g} / \mathrm{ml}$ DAPI in PBS. Non-specific mouse IgG was used instead of mouse anti-bovine class II MHC $\mathrm{mAbs}$ as a negative control to demonstrate specificity of antibody binding.

Tissue sections were examined using an Olympus BX51 microscope equipped with an Olympus reflected fluorescence system (Olympus America, Melville, NY, USA). Images were collected using an Olympus MagnaFire digital camera. Fluorescence micrographs were qualitatively assessed to determine the identity of cells expressing class II MHC molecules.

\section{Isolation and culture of mixed luteal cells and luteal endothelial cells}

Cultures of mixed luteal cells were prepared from bovine $\mathrm{CL}$ using procedures described previously (Pate

Table 1 Primary antibodies used in immunohistochemistry.

\begin{tabular}{llll}
\hline Antibody & Specificity & Source & Working dilution \\
\hline H42A & Bovine class II MHC DP & VMRD, Pullman, WA, USA & $1: 2000$ \\
TH81A5 & Bovine class II MHC DQ & VMRD, Pullman, WA, USA & $1: 2000$ \\
TH14B & Bovine class II MHC DRa & VMRD, Pullman, WA, USA & $1: 2000$ \\
RDI-P450 SCCabr & Bovine CYP11A1 & Research Diagnostics, Concord, MA, USA & $1: 1000$ \\
DH59B & CD172a (bovine monocytes/granulocytes) & VMRD, Pullman, WA, USA & $1: 200$ \\
EBM11 & CD68 (bovine activated macrophages) & Dako, Carpinteria, CA, USA & $1: 150$ \\
\hline
\end{tabular}


\& Condon 1982). Cell culture was performed in a humidified atmosphere of $5 \% \mathrm{CO}_{2}$ in air at $37^{\circ} \mathrm{C}$. Dispersed luteal cells $\left(4 \times 10^{6}\right.$ cells/flask) were cultured in serum-coated $25 \mathrm{~cm}^{2}$ flasks in a total of $4 \mathrm{ml}$ Hams F-12 containing insulin $(5 \mu \mathrm{g} / \mathrm{ml})$, transferrin $(5 \mu \mathrm{g} / \mathrm{ml})$, selenium (5 $\mathrm{ng} / \mathrm{ml})$, gentamicin $(20 \mu \mathrm{g} / \mathrm{ml})$, and $\mathrm{LH}(1 \mathrm{ng} / \mathrm{ml})$. The cells were allowed to adhere overnight, medium was replaced, and the cultures were exposed to either 0 or $50 \mathrm{ng} / \mathrm{ml}$ TNF for $48 \mathrm{~h}$, the latter concentration having been shown to affect function, viability, and gene expression in cultures of mixed bovine luteal cells (Townson \& Pate 1994, Petroff et al. 2001, Cannon \& Pate 2003). Total RNA was extracted from the cells after $48 \mathrm{~h}$ of culture. Culture experiments were repeated thrice.

Purified endothelial cells from bovine CL (CLENDO cells) were purchased from Cambrex Bioscience (BioWhittaker, Inc., Walkersville, MD, USA), as described previously (Cavicchio et al. 2002, Pru et al. 2003, Liptak et al. 2005). In the present study, endothelial cells from frozen aliquots (passages 3-5; $5000 \mathrm{cells} / \mathrm{cm}^{2}$ ) were cultured in a growth factor-containing medium (microvascular endothelial cell medium-2 (EGM-2MV)), as recommended by the supplier with $3 \%$ fetal bovine serum in $60 \mathrm{~mm}$ dishes. Cultures were maintained at $37^{\circ} \mathrm{C}$ in a humidified atmosphere of $5 \% \mathrm{CO}_{2}$ and $95 \%$ air. Culture medium was replaced every $48 \mathrm{~h}$ until cells were 80-90\% confluent, at which point medium was changed and cultures were maintained in a basal (serum- and growth factor-free) endothelial cell basal medium (EBM-2) medium for $24 \mathrm{~h}$, as described (Pru et al. 2003). Prior to treatment, the medium was removed and replaced with fresh EBM-2 for an equilibration period of $3 \mathrm{~h}$ before the administration of treatments. Cultured cells were then treated with 0 or $50 \mathrm{ng} / \mathrm{ml} \mathrm{TNF}$ for $48 \mathrm{~h}$, the latter concentration having been shown to induce signal transduction pathways in bovine CLENDO cells (Pru et al. 2003). Total RNA was extracted from cells after $48 \mathrm{~h}$ of culture. Culture experiments were repeated thrice.

\section{RNA extraction and RT-quantitative PCR (RT-qPCR)}

RNA was extracted from luteal tissue collected during the estrous cycle using TRIzol reagent. Frozen luteal tissue was homogenized in TRIzol using a Polytron tissue homogenizer (Brinkman Instruments, Westbury, NY, USA), and total cellular RNA was isolated according to manufacturer's specifications. For extraction of total RNA from mixed luteal cell or CLENDO cultures, cells were collected in RLT lysis buffer and RNA was isolated using the RNeasy kit (Qiagen) according to the procedures specified by the manufacturer.

Sequences, annealing conditions, GenBank accession numbers for corresponding targets, and references (Aida et al. 1994, Hartung et al. 1995, Stewart et al. 1996) for primer sequences used in RT-PCR are listed in Table 2. Steady-state concentrations of DRA and GAPDH mRNA were determined in total RNA extracted from bovine luteal tissues ( $n=5 \mathrm{CL}$ per time point). Concentrations of DRA and GAPDH mRNA were also determined in total RNA isolated from cultures of mixed luteal cells $(n=3)$ and CLENDO cells $(n=3)$. In addition, the presence and relative abundance of STAR and PECAM1 (a cell adhesion molecule used as an endothelial cell marker; Albelda et al. 1990, Levy et al. 2001) mRNAs were assessed in mixed luteal and CLENDO cell culture samples as a means of determining purity and composition of cultures.

PCR procedures were performed using an MJ Research Opticon 2 real-time PCR thermal cycler. Prior to PCR, RT using random hexamer primers was performed on $2 \mu \mathrm{g}$ total RNA. PCR was then performed on $200 \mathrm{ng}$ reverse-transcribed cDNA, using the DyNAmo HS SYBR Green qPCR kit according to manufacturer's instructions. Thermal cycling was carried out using the following conditions: denaturation at $94{ }^{\circ} \mathrm{C}$ for $30 \mathrm{~s}$; annealing (see Table 2 for temperatures) for $30 \mathrm{~s}$; and extension at $72{ }^{\circ} \mathrm{C}$ for $60 \mathrm{~s}$, for a total of 32 cycles. Fluorescence values in each tube were measured at the end of each cycle using single acquisition mode. Melting curve analysis was performed after the end of the last cycle. Melting curve analysis in conjunction with gel electrophoresis of amplified products was used to verify amplification of a single product in each sample, and identification of amplified products was confirmed by sequencing.

Table 2 Primer sequences used in real-time RT-PCR assays.

\begin{tabular}{|c|c|c|c|c|c|}
\hline Target & Primer sequence & $\begin{array}{l}\text { Amplicon } \\
\text { size (bp) }\end{array}$ & $\begin{array}{c}\text { Annealing } \\
\text { temperature }\left({ }^{\circ} \mathrm{C}\right)\end{array}$ & $\begin{array}{c}\text { GenBank } \\
\text { accession no. }\end{array}$ & Reference \\
\hline DRA & $\begin{array}{l}\text { Forward: 5'-GGAAGAAGGAGACGGTGT-3' } \\
\text { Reverse: 5'-CAGGAAGACCGTCTGTGA-3' }\end{array}$ & 305 & 54 & X78308 & Aida et al. (1994) \\
\hline PECAM1 & $\begin{array}{l}\text { Forward: 5'-GTTCAGCGAAGTTCTGCGAG-3' } \\
\text { Reverse: } 5^{\prime} \text {-CTTGCTGGCTGTGGTCTTGT-3' }\end{array}$ & 229 & 58 & U35433 & Stewart et al. (1996) \\
\hline GAPDH & $\begin{array}{l}\text { Forward: 5'-AAGATTGTCAGCAATGCC-3' } \\
\text { Reverse: 5'-ACAGACACGTTGGGAG-3' }\end{array}$ & 293 & 56 & BC102589 & - \\
\hline STAR & $\begin{array}{l}\text { Forward: 5'-CCTCTCTACAGCGACCAA-3' } \\
\text { Reverse: 5'-TCGTGAGTGATGACCGTG-3' }\end{array}$ & 311 & 58 & Y17259 & Hartung et al. (1995) \\
\hline
\end{tabular}


For RNA samples collected from luteal tissue during the estrous cycle, all samples were assayed in duplicate using DRA and GAPDH primers. Fluorescence values of $D R A$ from duplicate wells were standardized to the corresponding GAPDH values. Standardized values were then used to calculate steady-state concentrations of $D R A$ message in each sample, using a homologous standard curve prepared from a purified DRA PCR product. Similar procedures were performed on RNA samples from mixed luteal and CLENDO cell cultures. In addition, the presence and abundance of STAR and PECAM1 mRNAs in samples isolated from these cultures were assessed. Fluorescence values for STAR and PECAM1 amplifications were standardized to corresponding GAPDH values as described previously. Since no standard curve was used to quantify the concentrations of these messages, comparisons were made using mean fluorescence, as previously described (Cannon et al. 2006).

\section{Statistical analysis}

One-way ANOVA was performed to determine whether differences $(P<0.05)$ existed between mean steady-state $D R A$ mRNA concentrations in luteal tissue samples collected on different days of the estrous cycle. The Student-Newman-Keuls procedure was used to determine differences between specific means. Within each culture type, the effect of TNF on amounts of $D R A$, STAR, and PECAM1 mRNAs was determined using Student's $t$-test. Since TNF had no effect on the concentrations of any of these messages, data from untreated and TNF-treated cultures were pooled according to the cell type (mixed luteal or CLENDO cells), and differences in the amounts of DRA, STAR, and PECAM1 mRNAs between cell types were determined using Student's t-test.

\section{Results}

In order to determine whether steroidogenic cells of the bovine CL express class II MHC molecules, polyclonal anti-rat CYP11A1 was used to identify the steroidogenic cells, while a cocktail of three anti-bovine class II MHC mAbs was used to identify cells expressing class II MHC. Steroidogenic luteal cells were negative for class II MHC at all stages of the estrous cycle examined (Fig. 1). In days 4 and $5 \mathrm{CL}$, class II MHC mAbs labeled single cells dispersed throughout the tissue, which was similar to the staining pattern observed when luteal tissues were stained with anti-monocyte and -macrophage mAbs (Fig. 1a and $d$ versus $b$, c, e and f). In days 10-12 CL, class II MHC mAbs labeled single cells with an appearance similar to cells labeled by anti-monocyte and -macrophage mAbs (Fig. $1 \mathrm{~g}$ versus $\mathrm{h}$ and $\mathrm{i}$ ), and also cells with a distribution and arrangement within the tissue reminiscent of capillary endothelial cells (Fig. $1 \mathrm{i}$, arrows). In day $18 \mathrm{CL}$, anti-class II MHC staining was similar to that observed in midcycle CL (Fig. $1 \mathrm{~g}-\mathrm{i}$ versus $\mathrm{j}-\mathrm{I})$, although the luteal microvasculature was less distinct at this time.

To determine whether endothelial cells expressed class II MHC, FITC-BS-1 was used to identify endothelial cells, while cells expressing class II MHC were identified as in the previous experiment. Similar to results in days 4 and $5 \mathrm{CL}$ from the previous experiment, class II MHC expression was localized to single cells dispersed throughout the tissue. Endothelial cells expressing class II MHC were not present in early $\mathrm{CL}$, as indicated by a lack of colocalization of class II MHC and FITC-BS-1 staining (Fig. 2a, b, d and e). In days 10-12 CL, in addition to single class II MHC-expressing cells similar to those observed in the early CL, colocalization of FITCBS-1 and class II MHC staining revealed the presence of class II MHC-expressing endothelial cells (Fig. $2 \mathrm{~g}$ and $\mathrm{h}$, arrows), while other endothelial cells were negative for class II MHC. In day $18 \mathrm{CL}$, class II MHC expression was less distinct in endothelial cells, although some colocalization of FITC-BS-1 and class II MHC staining was apparent (Fig. $2 \mathrm{j}$ and k). Tissues in which primary antibodies were replaced with non-immune rabbit serum or non-specific mouse $\lg G$ were devoid of staining throughout (Fig. 2C, f, i and l; data for non-immune rabbit serum not shown). To determine whether luteal endothelial cells express each of the three types of class II MHC molecules (DP, DQ, and DR), the mAbs used as a cocktail in the first and second immunohistochemical studies were applied individually to stain midcycle luteal tissue in a third study. Endothelial cells in the midcycle CL expressed only DR (Fig. 3).

Steady-state concentrations of DRA mRNA were lower in days 4 and $5 \mathrm{CL}$ when compared with those in day 18 $\mathrm{CL}$ (Fig. $4 ; P<0.05 ; n=5 \mathrm{CL}$ per time point). The variation in DRA mRNA concentration was highest in the midcycle $\mathrm{CL}$ when compared with the other times examined; therefore, although the concentration of $D R A$ mRNA appears higher in the midcycle $\mathrm{CL}$ when compared with that in days 4 or $5 \mathrm{CL}$, this difference was not significant $(P>0.05)$.

To further confirm the expression of DRA by luteal endothelial cells, the presence and steady-state concentrations of DRA mRNA in cultures of mixed luteal and CLENDO cell cultures were evaluated. The purity of culture types was assessed using RT-qPCR to measure amounts of STAR and PECAM1 mRNAs in samples from each culture, and the PCR was allowed to continue for a maximal number of cycles to amplify even the slightest amount of these two mRNAs. After 45 cycles, electrophoretic analysis revealed a single $311 \mathrm{bp}$ amplicon of STAR mRNA in some samples from CLENDO cultures, while large amounts of PECAM1 mRNA were present in all CLENDO cell 

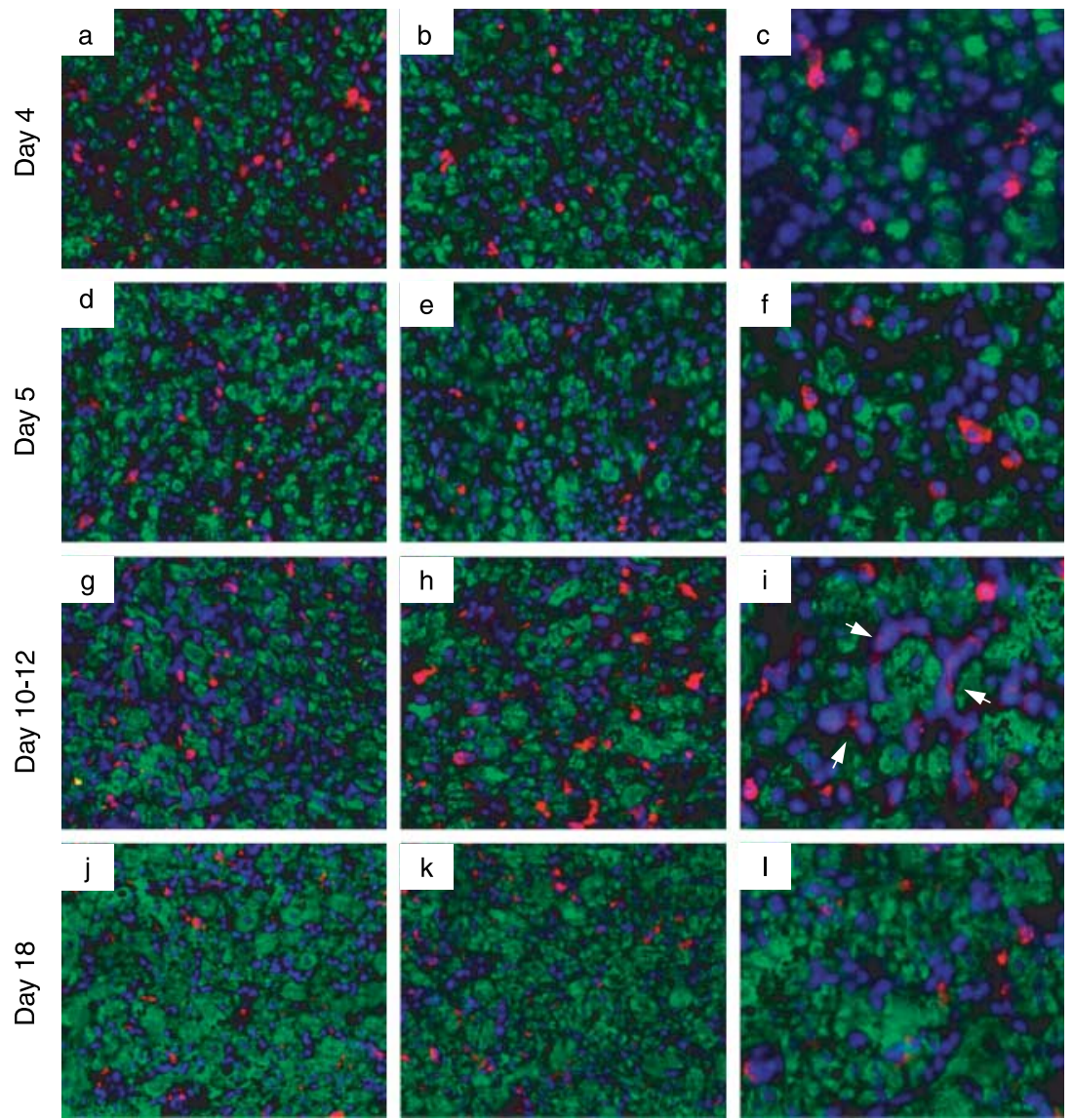

anti-monocyte/ macrophage mAbs (200x magnification)

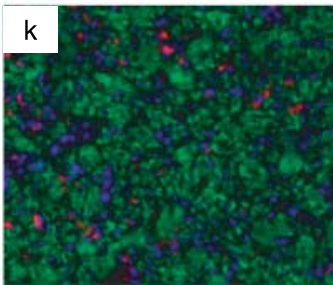

anti-class II MHC mAbs (200x magnification)
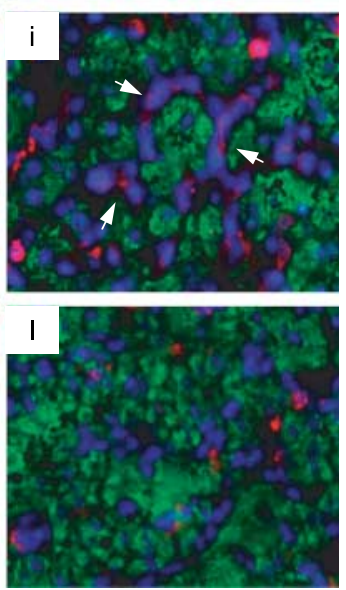

anti-class II MHC mAbs (400x magnification)
Figure 1 Fluorescent micrographs of bovine luteal tissue sections $(7 \mu \mathrm{m})$ collected on days 4,5 , $10-12$, and 18 of the estrous cycle. Steroidogenic cells were identified with anti-CYP11A1 antiserum (green fluorescence) and cells expressing class II MHC were identified using anti-class II MHC mAbs (red fluorescence in b, c, e, f, h, i, k, and I). Sections were also labeled with anti-monocyte and -macrophage mAbs (red fluorescence in a, $d$, $\mathrm{g}$, and j). Cell nuclei were visualized with DAPI (blue fluorescence). White arrows (i) indicate putative endothelial cells labeled with class II MHC mAbs. Magnifications are listed below each column. cultures (Fig. 5a, upper panels). TNF had no effect on the abundance of STAR or PECAM1 mRNA in CLENDO cells $(P>0.05, n=3$; data not shown). In samples from mixed luteal cell cultures, STAR mRNA was abundant, and a single 229 bp PECAM1 amplification product was also clearly visible (Fig. 5a, lower panels). TNF did not affect amounts of STAR or PECAM1 mRNA in mixed luteal cell cultures $(P>0.05$, $n=3$; data not shown). The concentration of STAR mRNA was much higher $(P<0.05)$ in mixed luteal cell cultures when compared with that in CLENDO cultures in which STAR mRNA was detectable, while the concentration of PECAM1 mRNA was approximately tenfold higher $(P<0.05, n=3)$ in CLENDO cells when compared with that in mixed luteal cells (Fig. 5b). A single 305 bp amplification product corresponding to DRA mRNA was present in cultures of CLENDO cells as well as in mixed luteal cells (Fig. 6, upper panel). TNF had no effect on DRA mRNA concentrations in both cultured cell types ( $P>0.05$; Fig. 6, graphs), and concentrations of DRA mRNA were not different between cultures of mixed luteal and CLENDO cells $(P>0.05)$.

\section{Discussion}

In the present study, we have demonstrated the expression of the class II MHC molecule DR by endothelial cells of the bovine $\mathrm{CL}$. In the early $\mathrm{CL}$, we observed class II MHC expression on single cells with a tissue distribution similar to monocytes and macrophages (Penny et al. 1999, Townson et al. 2002; and present study). Expression of class II MHC on macrophages is not surprising and would be expected. However, in midcycle (days 10-12) CL, staining was also observed on cells, whose distribution and architecture relative to the surrounding tissue were reminiscent of endothelial cells (Farin et al. 1986, O'Shea et al. 1989). In the second experiment, class II $\mathrm{MHC}$ was colocalized with a subpopulation of endothelial cells in the midcycle CL. Further investigation revealed that these cells express only DR, while putative macrophages express all the three types of class II MHC molecules, DP, DQ, and DR. However, not all endothelial cells were labeled with class II MHC mAbs, and expression of class II MHC by endothelial cells was less distinct in late $C L$, possibly due to the loss of a well-defined microvasculature relative to the midcycle $\mathrm{CL}$. 

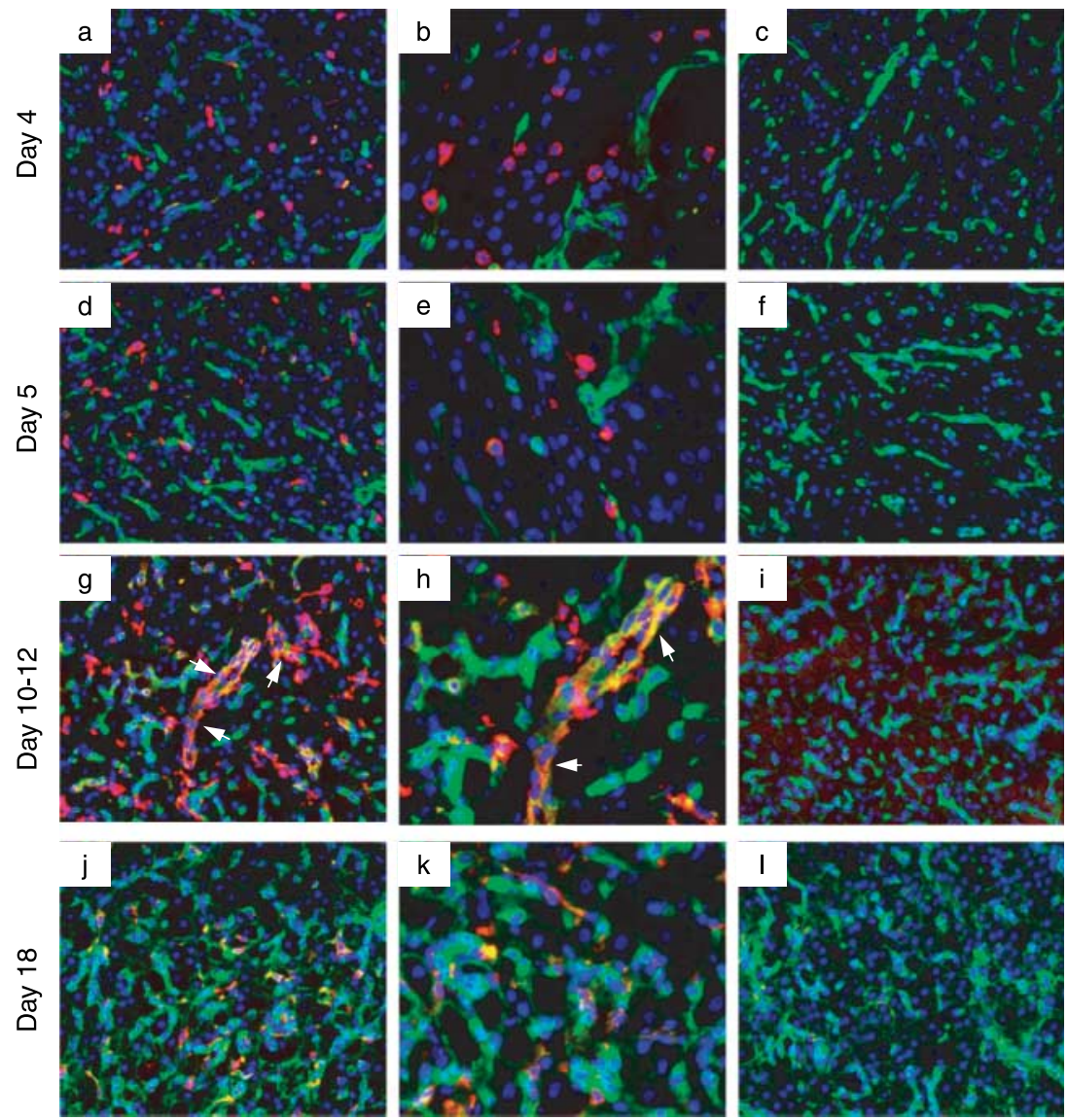

anti-class II mAbs + FITC-BS-1

(200x magnification) anti-class II mAbs + FITC-BS-1

(400x magnification)

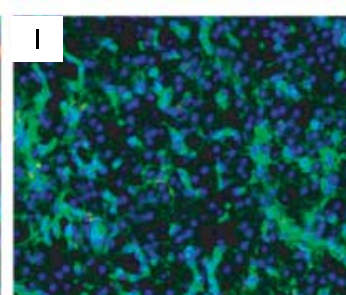

NslgG +

FITC-BS-1

(200x magnification)
Figure 2 Fluorescent micrographs of bovine luteal tissue sections $(7 \mu \mathrm{m})$ collected on days 4,5 , 10-12, and 18 of the estrous cycle. Endothelial cells were identified with FITC-labeled BS-1 lectin (green fluorescence) and cells expressing class II MHC were identified using anti-class II MHC mAbs (red fluorescence). Cell nuclei were visualized with DAPI (blue fluorescence). Yellow staining indicates colocalization of FITC-BS-1 lectin and class II MHC mAbs. White arrows ( $g$ and $h$ ) indicate endothelial cells expressing class II MHC. Sections in which anti-class II MHC $1^{\circ} \mathrm{mAbs}$ were substituted with non-specific IgG (c, f, i, and I) are shown to demonstrate antibody specificity. Magnifications are listed below each column.
Steady-state concentrations of DRA mRNA were higher in the late $C L$ relative to the early $C L$, but due to a large amount of variation among animals, concentrations of DRA mRNA in the midcycle $\mathrm{CL}$ were not significantly different from the early or late CL. This increase in DRA expression is consistent with the expression of DRA protein by both putative macrophages and a subpopulation of endothelial cells in the midcycle and late $\mathrm{CL}$, whereas only putative macrophages in the early CL express class II MHC. The elevation in steady-state DRA mRNA concentrations as the $\mathrm{CL}$ ages also agrees with the flow cytometric data of Benyo et al. (1991), who observed an increase in the number of class II MHC-expressing cells in the midcycle $\mathrm{CL}$ when compared with that in the early $\mathrm{CL}$ using flow cytometry.

Expression of class II MHC in the bovine $\mathrm{CL}$ has been examined in previous studies, with varying results. Fairchild \& Pate (1989) initially demonstrated that IFNG induces expression of class II MHC on cultured bovine luteal cells, and the aforementioned flow cytometric study (Benyo et al. 1991) subsequently evaluated the expression of class II MHC on freshly isolated cells from dispersed bovine CL. Flow cytometric evaluation of dispersed bovine luteal cells in that study revealed three cell populations in midcycle and late luteal tissue: small cells (which presumably consist of small steroidogenic cells and macrophages, since cell $<10 \mu \mathrm{m}$ were excluded from analysis), large dense cells, and large less dense cells. The small and large less dense cells expressed class II MHC in the midcycle and late $\mathrm{CL}$. The existence of two populations of large luteal cells, differing in amount of secretory granules and intracellular lipid droplets, had been noted previously (Hansel et al. 1987). However, when considering the data from the present study, it seems plausible that the large less dense cells expressing class II MHC in the study by Benyo et al. (1991) may have been small clusters of class II MHC-expressing endothelial cells, rather than single large cells. In preliminary immunofluorescent studies, we observed small clusters of endothelial cells labeled with class II MHC mAbs in dispersed luteal cell suspensions. These clusters were composed typically of four to eight endothelial cells, and were of similar size to large steroidogenic luteal cells (Cannon \& Pate unpublished observations). 

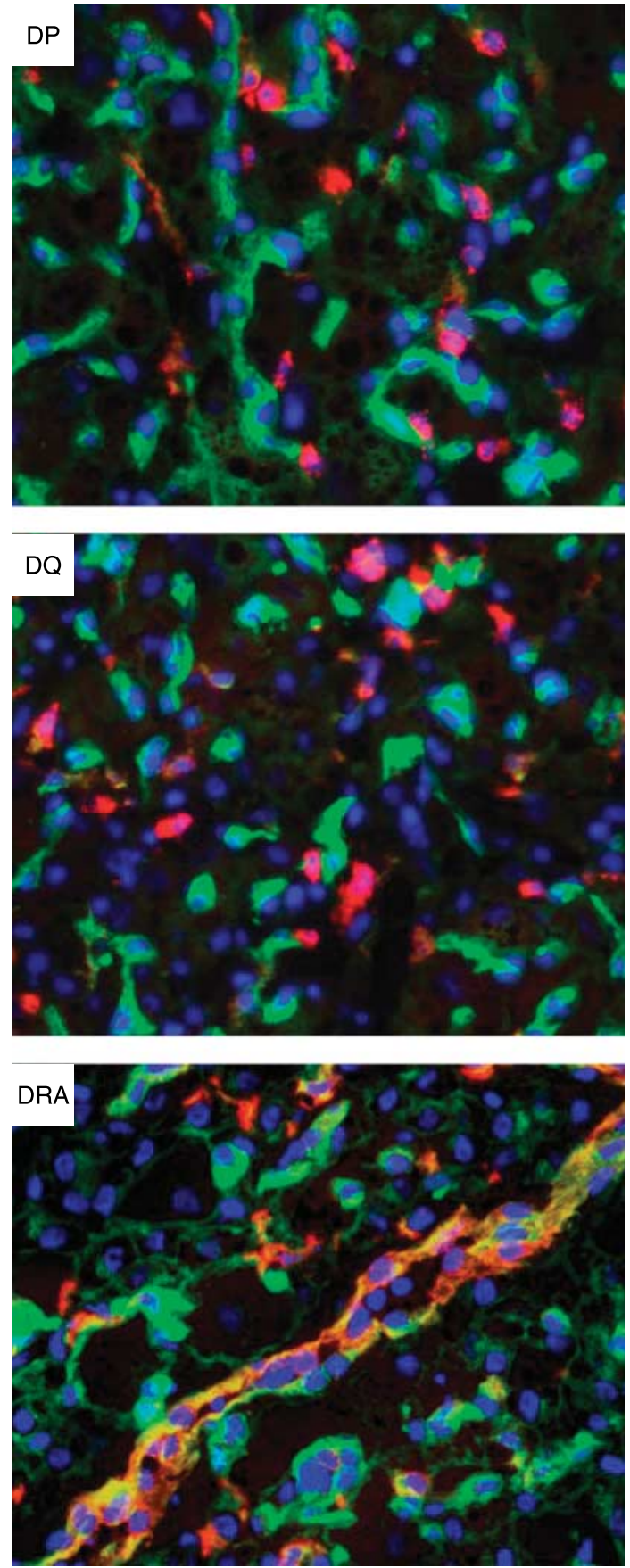

Figure 3 Fluorescent micrographs of midcycle (day 10) bovine luteal tissue sections $(7 \mu \mathrm{m})$ stained with mAbs H42A (DP), TH81A5 (DQ), or TH14B (DRA) individually (red fluorescence). Endothelial cells were identified with FITC-labeled BS-1 lectin (green fluorescence). Cell nuclei were visualized with DAPI (blue fluorescence). Yellow staining indicates colocalization of FITC-BS-1 and class II MHC mAbs. Magnification, $200 \times$.

Therefore, it is possible that the class II MHC-positive large less dense cells originally observed (Benyo et al. 1991) consisted, at least in part, of small clusters of DR-expressing luteal endothelial cells. The results of that study agree with those of the present study, in that

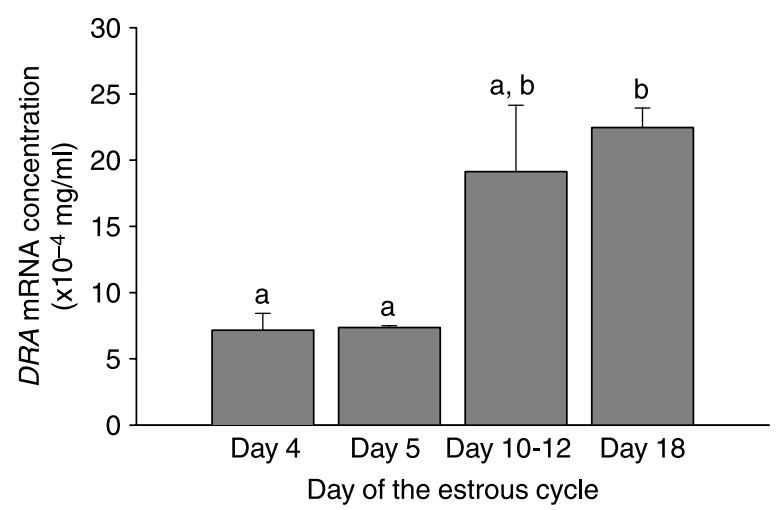

Figure 4 Steady-state concentrations of DRA mRNA in bovine $\mathrm{CL}$ collected during the estrous cycle. Bars represent mean concentrations of DRA mRNA in total RNA samples extracted from luteal tissue collected on days $4,5,10-12$, or 18 of the estrous cycle ( $n=5 \mathrm{CL}$ per time point). Different letters denote significant differences $(P<0.05)$.

large dense cells in that study (presumably steroidogenic luteal cells) did not express class II MHC at any time during the estrous cycle.

The presence of cells expressing DRA was observed in a more recent immunohistochemical study (Penny et al. 1999), but these authors did not identify the individual cell type(s) expressing DRA. The methods employed differ somewhat from those of the present study, in that we have used immunofluorescent techniques to localize antibody binding, whereas Penny et al. (1999) used enzymatically based colorimetric detection. Additionally, acetone was used as a fixative for frozen sections in that study, but we have found that, at least in our hands, ethanol is superior to acetone for maintaining cell morphology and tissue architecture in frozen luteal tissue sections, thus allowing for better resolution of cell types.

Our results appear to agree with those of Lehman et al. (2000), who observed class II MHC expression on a subpopulation of cultured endothelial cells derived from bovine CL. Flow cytometry was used in that study to evaluate class II MHC expression on various cultured bovine luteal endothelial cell subtypes (Lehman et al. 2000), and therefore no information on expression of class II MHC by endothelial cells in situ could be derived. Ours is the first study, to the best of our knowledge, in which the expression in situ of class II MHC by bovine luteal endothelial cells has been demonstrated.

Cultures of mixed luteal and CLENDO cells were used to further confirm the observation that the class II MHC molecule DR is expressed by luteal endothelial cells. Analysis of STAR and PECAM1 mRNAs indicated that the CLENDO cell cultures used in the present study were highly enriched cultures of luteal endothelial cells, whereas the mixed luteal cell cultures were composed largely of steroidogenic cells, but were also likely to contain some endothelial cells. DRA mRNA was found in both mixed luteal and CLENDO cell cultures, with no 
A

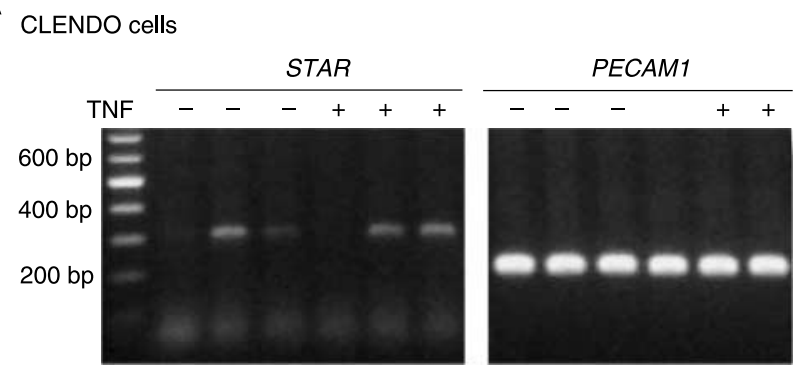

Mixed luteal cells

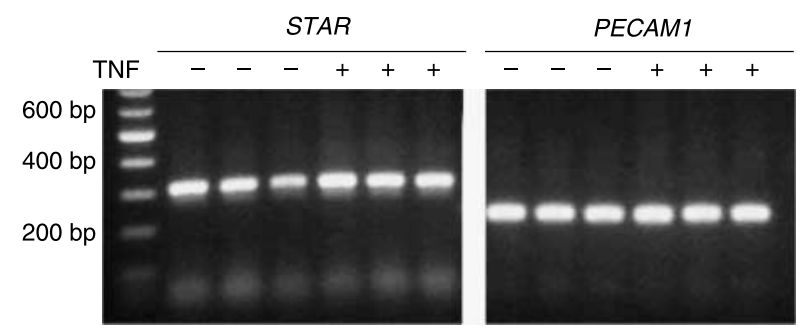

B

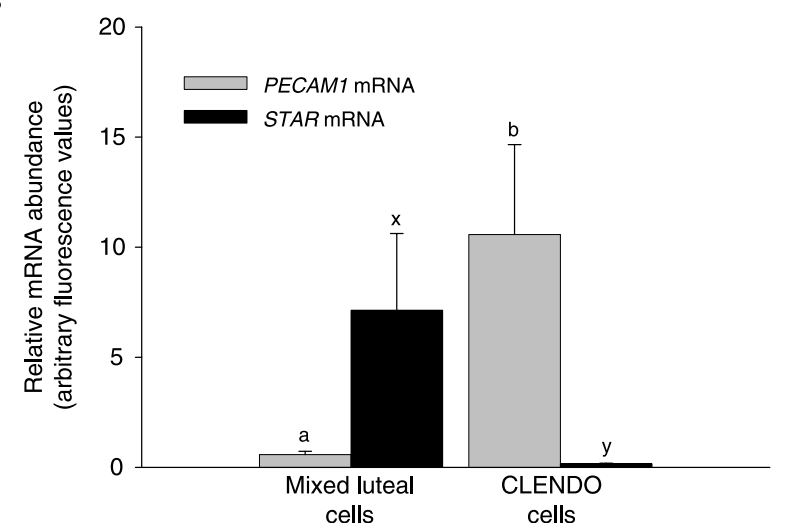

Figure 5 (A) Agarose gels showing PCR amplification products using STAR- and PECAM1-specific primers in samples extracted from cultures of CLENDO cells (top panel) or mixed luteal cells (bottoms panel). Cultures were treated with 0 or $50 \mathrm{ng} / \mathrm{ml} \mathrm{TNF} \mathrm{(} n=3$ cultures per treatment) for $48 \mathrm{~h}$. (B) Relative abundance of STAR and PECAM1 mRNA in cultures of CLENDO and mixed luteal cells. Bars represent mean amounts of PECAM1 (gray bars) or STAR (black bars) mRNAs (expressed in arbitrary fluorescence units) in samples extracted from CLENDO or mixed luteal cell cultures. Different letters indicate a difference in relative abundance of mRNA between CLENDO ( $a$ and $b$ ) and mixed luteal cell ( $x$ and $y)$ cultures $(P<0.05, n=3)$.

differences in steady-state concentrations of DRA mRNA between cultures. The presence of DRA mRNA in CLENDO cultures confirms the immunohistochemical results demonstrating the presence of DRA in endothelial cells of the CL. The presence of relatively large amounts of DRA mRNA in mixed luteal cell cultures seems enigmatic, given the lack of expression of class II MHC by steroidogenic cells observed throughout the first part of this study. Macrophages, along with the minor endothelial cell contaminant suspected to be present in mixed luteal cell cultures, could account for the presence of $D R A$ mRNA in these cultures. Alternatively, steroidogenic cells may contain DRA mRNA, but express an aberrant form of the protein that is not recognized by the antibody using immunohistochemical methods. Finally, the possibility exists that a distinct cell type, which is localized adjacent to endothelial cells in tissue sections, but is not isolated with CLENDOS, is responsible for DRA expression. Such non-professional antigen-presenting cells (ITO cells) have been identified in the liver (Winau et al. 2007), but no such cell has yet been described in the CL.

It was of interest to note that TNF had no effect on STAR, PECAM1, or DRA mRNA concentrations in both mixed luteal and CLENDO cells. TNF has been shown to reduce steady-state PECAM1 mRNA concentrations in bovine endothelial cells (Stewart et al. 1996). However, in the flow cytometric study by Lehman et al. (2000), TNF had no effect on PECAM1 and class II MHC expression in cultured bovine luteal endothelial cells, which supports the present findings.

Endothelial cells make up an estimated $50 \%$ of the cells in the CL (Farin et al. 1986, O'Shea et al. 1989), and a great deal of attention has been focused on the role of endothelial cells in luteal function. Prostaglandin $F_{2 \alpha}$ enhanced the production of endothelin-1 (EDN1) by luteal endothelial cells in vitro (Girsh et al. 1996a), and EDN1 inhibited progesterone production by cultured luteal-like cells (Girsh et al. 1996b), presumably via a protein kinase C-dependent pathway (Sen et al. 2006). TNF stimulated the secretion of $\mathrm{PGF}_{2 \alpha}, \mathrm{EDN1}$, and monocyte chemoattractant protein 1 (CCL2) by luteal endothelial cells (Okuda et al. 1999, Cavicchio et al. 2002), and induced apoptosis of luteal endothelial cells, possibly via a ceramidedependent mechanism that involved the production of reactive oxygen species (Pru et al. 2003). In addition, activated lymphocytes stimulated CCL2 secretion by cultured luteal endothelial cells, and this stimulation was contact dependent (Liptak et al. 2005). It is unknown whether this contact-dependent stimulation was MHC dependent. However, it is possible that within the midcycle $C L$, endothelial cells interact with lymphocytes in a class II MHC-dependent manner, resulting in the production of CCL2 by endothelial cells. Class II MHCdependent activation of T lymphocytes by bovine luteal cells has been demonstrated in vitro (Petroff et al. 1997).

Microvascular endothelial cells play an integral role in the regulation of the immune system, since they regulate recruitment of T cells into the tissue via chemokine and cell surface adhesion molecule expression (Pober 1999). Expression of class II MHC molecules by endothelial cells is most often associated with either pathogenic autoimmune disease or graft rejection (Denton et al. 1999, Turesson 2004), although some types of endothelial cells apparently express class II MHC molecules in the absence of a pathological inflammatory condition (Pober 1999). The common belief that class II MHC expression by endothelial cells results in stimulation of T-cell activation by endothelial cells is supported by numerous studies 


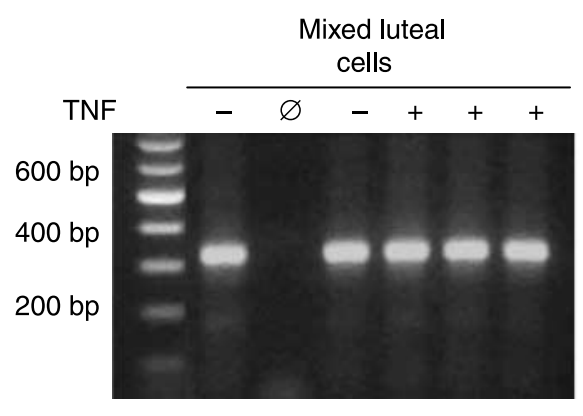

DRA mRNA in mixed luteal cells

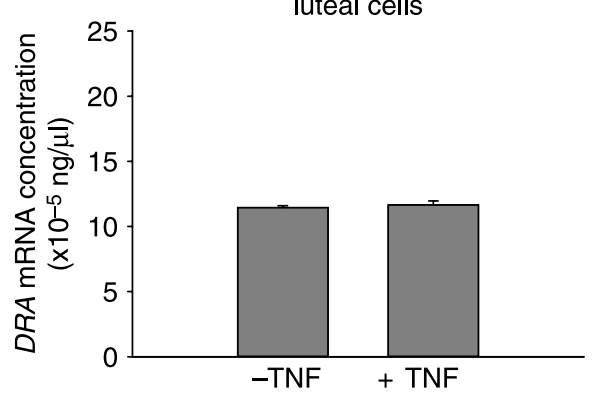

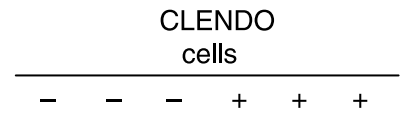

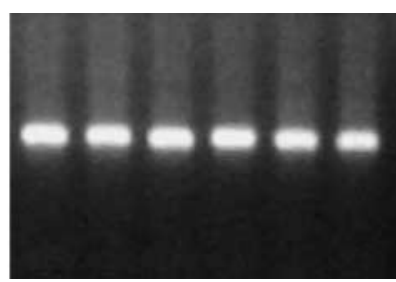

DRA mRNA in CLENDO cells

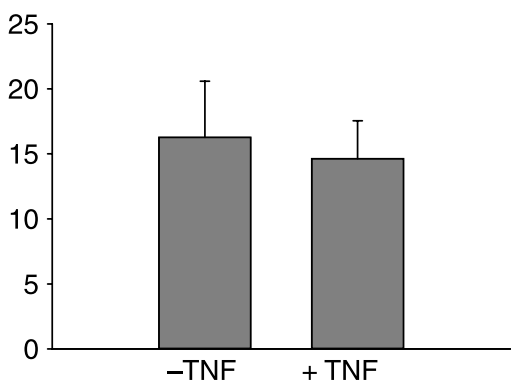

Figure 6 Expression of DRA in CLENDO and mixed luteal cell cultures. Upper panels display agarose gels showing PCR amplification products using $D R A$-specific primers in samples extracted from CLENDO or mixed luteal cell cultures. $\varnothing$ indicates a lost sample (empty gel lane). Graphs show steady-state concentrations of DRA mRNA in cells cultured in the absence or presence of $50 \mathrm{ng} / \mathrm{ml} \mathrm{TNF}(n=3$ cultures per treatment). Bars represent mean concentrations of DRA mRNA in total RNA extracted from CLENDO or mixed luteal cell cultures.
(Choi et al. 2004). However, T-cell activation by class II MHC-expressing endothelial cells should not be considered the rule, since there are notable exceptions in which endothelial cells do not induce T-cell activation (Marelli-Berg etal. 1996, 1999, Katz et al. 2004) and even induce T-cell anergy, an induced state of inactivation (Denton et al. 1999, Kawai et al. 2000, Khayyamian et al. 2002, Appleman \& Boussiotis 2003, Tokita et al. 2006). In addition to induction of anergy, microvascular endothelial cells from other tissues can also promote production of pro-inflammatory as well as anti-inflammatory cytokines by $\mathrm{T}$ lymphocytes, and these observations demonstrate the ability of endothelial cells to regulate the activity of migrating $\mathrm{T}$ lymphocytes.

With regard to the $\mathrm{CL}$, microvascular endothelial cells are the first cells that will be encountered by $T$ lymphocytes circulating through and infiltrating the CL. It is therefore likely that luteal endothelial cells, by necessity, interact with infiltrating $\mathrm{T}$ lymphocytes, and in doing so may regulate their effector functions. It is noteworthy that several recent studies have observed increases in immune cells, cytokines, and expression of genes significant to immune function in the midcycle $\mathrm{CL}$ (Townson et al. 2002, Cannon \& Pate 2003, Cannon et al. 2006), while several reports demonstrate supportive effects of secreted products of macrophages and $\mathrm{T}$ lymphocytes on luteal cell function (Hughes et al. 1991, Chen et al. 1992, Ness \& Kasson 1995, Sugino et al. 1998, Pate \& Keyes 2001). Expression of the class II MHC molecule DR by a subpopulation of luteal endothelial cells may be a means by which regulation of infiltrating $T$ lymphocytes takes place. Thus, although it has been suggested for some time that the immune system facilitates the process of luteal regression (Pate 1995, Davis \& Rueda 2002), it may be possible that the immune system also participates in maintenance of normal luteal function. In this scenario, class II MHC-expressing luteal endothelial cells could induce a state of anergy in T cells infiltrating the $C L$ during the luteal phase, thus preventing potentially detrimental activation of $\mathrm{T}$ cells prior to the time of luteal regression. In light of the present findings, the role of the immune system in regulation of luteal function may need to be reconsidered, in that the immune system may not only facilitate luteal regression, but also support development and normal function of the CL prior to initiation of luteolysis.

In conclusion, we have presented the evidence that a subpopulation of endothelial cells in the bovine $\mathrm{CL}$ expresses the class II MHC molecule DR, with expression absent in the early $\mathrm{CL}$ but present and readily detectable at midcycle, and also in late CL. CLENDO cells were shown to contain DRA mRNA, confirming the immunohistochemical observations from the first part of the study. The precise role of DR expression on bovine luteal endothelial cells remains to be determined, but it is possible that DR expression on luteal endothelial cells during midcycle modulates the response of $\mathrm{T}$ lymphocytes present in the luteal microvasculature in a way that supports normal luteal function.

\section{Acknowledgements}

The authors gratefully acknowledge the technical assistance of Michelle Stone. This work was supported by NIH grants HD37550 to JLP and HD48754 to JSD, and funds from the DVA to JSD. Salaries and research support are also provided by State 
and Federal funds appropriated. The authors declare that there is no conflict of interest that would prejudice the impartiality of this scientific work.

\section{References}

Aida Y, Kohda C, Morooka A, Nakai Y, Ogimoto K, Urao T \& Asahina M 1994 Cloning of cDNAs and the molecular evolution of a bovine MHC class II DRA gene. Biochemical and Biophysical Research Communications 204 195-202.

Albelda SM, Oliver PD, Romer LH \& Buck CA 1990 EndoCAM: a novel endothelial cell-cell adhesion molecule. Journal of Cell Biology $\mathbf{1 1 0}$ 1227-1237.

Alpizar E \& Spicer LJ 1994 Effects of interleukin-6 on proliferation and follicle-stimulating hormone-induced estradiol production by bovine granulosa cells in vitro: dependence on size of follicle. Biology of Reproduction 50 38-43.

Altman A, Mustelin T \& Coggeshall KM 1990 T lymphocyte activation: a biological model of signal transduction. Critical Reviews of Immunology 10 347-391.

Appleman LJ \& Boussiotis VA 2003 T cell anergy and costimulation. Immunological Reviews 192 161-180.

Bagavandoss P, Wiggins RC, Kunkel SC, Remick DG \& Keyes PL 1990 Tumor necrosis factor production and accumulation of inflammatory cells in the corpus luteum of pseudo-pregnancy and pregnancy in rabbits. Biology of Reproduction 42 367-376.

Benyo DF \& Pate JL 1992 Tumor necrosis factor- $\alpha$ alters bovine luteal cell synthetic capacity and viability. Endocrinology 130 854-860.

Benyo DF, Haibel GK, Laufman HB \& Pate JL 1991 Expression of major histocompatibility complex antigens on the bovine corpus luteum during the estrous cycle, luteolysis, and early pregnancy. Biology of Reproduction 45 229-234.

Bowen JM \& Keyes PL 1999 The proestrous prolactin surge is not the sole initiator of regressive changes in corpora lutea of normally cycling rats. Biology of Reproduction 61 1208-1215.

Bowen JM \& Keyes PL 2000 Repeated exposure to prolactin is required to induce luteal regression in the hypophysectomized rat. Biology of Reproduction 63 1179-1184.

Bränström M, Giesecke L, Moore IC, van den Heuvel CJ \& Robertson SA 1994 Leukocyte subpopulations in the rat corpus luteum during pregnancy and pseudopregnancy. Biology of Reproduction $\mathbf{5 0} 1161-1167$.

Breard E, Benhaim A, Feral C \& Leymarie P 1998 Rabbit ovarian production of interleukin- 6 and its potential effects on gonadotropininduced progesterone secretion in granulosa and theca cells. Journal of Endocrinology 159 479-487.

Bukovský A, Caudle MR, Keenan JA, Wimalasena J, Upadhyaya NB \& Van Meter SE 1995 Is corpus luteum regression an immunemediated event? Localization of immune system components and luteinizing hormone receptor in human corpora lutea Biology of Reproduction 53 1373-1384.

Cannon MJ \& Pate JL 2003 Expression and regulation of interferon $\gamma$-inducible proteasomal subunits LMP7 and LMP10 in the bovine corpus luteum. Biology of Reproduction 68 1447-1454.

Cannon MJ, Davis JS \& Pate JL 2006 Presence and regulation of messenger ribonucleic acids encoding components of the class II major histocompatibility complex-associated antigen processing pathway in the bovine corpus luteum. Reproduction 131 689-698.

Cavicchio VA, Pru JK, Davis BS, Davis JS, Rueda BR \& Townson DH 2002 Secretion of monocyte chemoattractant protein-1 by endothelial cells of the bovine corpus luteum: regulation by cytokines but not prostaglandin F2 $\alpha$. Endocrinology 143 3582-3589.

Chen TT, Lane TA, Doody MC \& Caudle MR 1992 The effect of peritoneal macrophage-derived factor(s) on ovarian progesterone secretion and LH receptors: the role of calcium. American Journal of Reproductive Immunology 28 43-50.
Choi J, Enis DR, Koh KP, Shiao SL \& Pober JS 2004 T lymphocyteendothelial cell interactions. Annual Review of Immunology 22 683-709.

Clark LJ, Irving-Rodgers HF, Dharmarajan AM \& Rodgers RJ 2004 Theca interna: the other side of bovine follicular atresia. Biology of Reproduction 71 1071-1078.

Cresswell P, Ackerman AL, Giodini A, Peaper DR \& Wearsch PA 2005 Mechanisms of MHC class I-restricted antigen processing and crosspresentation. Annual Review of Immunology 207 145-157.

Davis JS \& Rueda BR 2002 The corpus luteum: an ovarian structure with maternal instincts and suicidal tendencies. Frontiers in Bioscience: a Journal and Virtual Library 7 d1949-d1978.

Del Vecchio RP \& Sutherland WD 1997 Prostaglandin and progesterone production by bovine luteal cells incubated in the presence or absence of the accessory cells of the corpus luteum and treated with interleukin-1beta, indomethacin and luteinizing hormone. Reproduction, Fertility, and Development 9 651-658.

Denton MD, Geehan CS, Alexander SI, Sayegh MH \& Briscoe DM 1999 Endothelial cells modify the costimulatory capacity of transmigrating leukocytes and promote CD28-mediated $\mathrm{CD}^{+} \mathrm{T}$ cell alloactivation. Journal of Experimental Medicine 190 555-566.

Fairchild DL \& Pate JL 1989 Interferon- $\gamma$ induction of major histocompatibility complex antigens on cultured bovine luteal cells. Biology of Reproduction 40 453-457.

Fairchild DL \& Pate JL 1991 Modulation of bovine luteal cell synthetic capacity by interferon-gamma. Biology of Reproduction $\mathbf{4 4}$ 357-363.

Farin CE, Moeller CL, Sawyer HR, Gamboni F \& Niswender GD 1986 Morphometric analysis of cell types in the ovine corpus luteum throughout the estrous cycle. Biology of Reproduction 35 1299-1308.

Fruh K, Ahn K \& Peterson PA 1997 Inhibition of MHC class I antigen presentation by viral proteins. Journal of Molecular Medicine $\mathbf{7 5}$ 18-27.

Girsh E, Milvae RA, Wang W \& Meidan R 1996a Effect of endothelin-1 on bovine luteal cell function: role in prostaglandin $F_{2 \alpha}$-induced antisteroidogenic action. Endocrinology 137 1306-1312.

Girsh E, Wang W, Mamluk R, Arditi F, Friedman A, Milvae RA \& Meidan R $1996 b$ Regulation of endothelin-1 expression in the bovine corpus luteum: elevation by prostaglandin $\mathrm{F}_{2 \alpha}$. Endocrinology 137 5191-5196.

Gorospe WC, Hughes FM Jr \& Spangelo BL 1992 Interleukin-6: effects on and production by rat granulosa cells in vitro. Endocrinology $\mathbf{1 3 0}$ 1750-1752.

Groothuis TA, Griekspoor AC, Neijssen JJ, Herberts CA \& Neefjes JJ 2005 MHC class I alleles and their exploration of the antigenprocessing machinery. Immunological Reviews 207 60-76.

Grusby MJ \& Glimcher LH 1995 Immune responses in MHC class Il-deficient mice. Annual Review of Immunology 13 417-435.

Hansel W, Alila HW, Dowd JP \& Yang X 1987 Control and steroidogenesis in small and large bovine luteal cells. Australian Journal of Biological Sciences 40 331-347.

Hartung S, Rust W, Balvers M \& Ivell R 1995 Molecular cloning and in vivo expression of the bovine steroidogenic acute regulatory protein. Biochemical and Biophysical Research Communications 215 646-653.

Hoffmann B, Busges F \& Baumgartner W 2004 Immunohistochemical detection of CD4-, CD8- and MHC II-expressing immune cells and endoglin in the canine corpus luteum at different stages of dioestrus. Reproduction in Domestic Animals 39 391-395.

Hughes FM Jr, Pringle CM \& Gorospe WC 1991 Production of progestin-stimulatory factor(s) by enriched populations of rat T and B lymphocytes. Biology of Reproduction 44 922-926.

Katz SC, Pillarisetty VG, Bleier JI, Shah AB \& DeMatteo RP 2004 Liver sinusoidal endothelial cells are insufficient to activate $\mathrm{T}$ cells. Journal of Immunology 173 230-235. 
Kawai T, Seki M, Watanabe H, Eastcott JW, Smith DJ \& Taubman MA $2000 \mathrm{~T}_{\mathrm{h}} 1$ transmigration anergy: a new concept of endothelial cell-T cell regulatory interaction. International Immunology 12 937-948.

Kelly MA, Rayner ML, Mijovic CH \& Barnett AH 2003 Molecular aspects of type 1 diabetes. Molecular Pathology 56 1-10.

Kenny N, Herman JR, Barisas BG \& Roess DA 1991 Flow cytometric analysis of class I and II MHC antigens on ovine luteal cell types. In Signaling Mechanisms and Gene Expression in the Ovary, pp 467-472. Ed. Gibori G. New York: Springer-Verlag.

Khayyamian S, Hutloff A, Buchner K, Grafe M, Henn V, Kroczek RA \& Mages HW 2002 ICOS-ligand, expressed on human endothelial cells, costimulates Th1 and Th2 cytokines secretion by memory CD4 ${ }^{+}$T cells. PNAS 99 6198-6203.

Khoury EL \& Marshall LA 1990 Luteinization of human granulosa cells in vivo is associated with expression of MHC class II antigens. Cell and Tissue Research 262 217-224.

Knolle PA \& Limmer A 2001 Neighborhood politics: the immunoregulatory function of organ-resident liver endothelial cells. Trends in Immunology 22 432-437.

Komatsu K, Manabe N, Kiso M, Shimabe M \& Miyamoto H 2003 Changes in localization of immune cells and cytokines in corpora lutea during luteolysis in murine ovaries. Journal of Experimental Zoology 296A 152-159.

Krusche CA, Vloet TD, Herrler A, Black S \& Beier HM 2002 Functional and structural regression of the rabbit corpus luteum is associated with altered luteal immune cell phenotypes and cytokine expression patterns. Histochemistry and Cell Biology 118 479-489.

Lawler DF, Hopkins J \& Watson DE 1999 Immune cell populations in the equine corpus luteum throughout the oestrous cycle and early pregnancy: an immunohistochemical and flow cytometric study. Journal of Reproduction and Fertility 117 281-290.

Lehman I, Brylla E, Sittig D, Spanel-Borowski K \& Aust G 2000 Microvascular endothelial cells differ in their basal and tumour necrosis factor- $\alpha$-regulated expression of adhesion molecules and cytokines. Journal of Vascular Research 37 408-416.

Levy N, Gordin M, Mamluk R, Yanagisawa M, Smith MF, Hampton JH \& Meidan R 2001 Distinct cellular localization and regulation of endothelin-1 and endothelin-converting enzyme-1 expression in the bovine corpus luteum: implications for luteolysis. Endocrinology 142 5254-5260.

Liptak AR, Sullivan BT, Henkes LE, Wijayagunawardane MP, Miyamoto A, Davis JS, Rueda BR \& Townson DH 2005 Cooperative expression of monocyte chemoattractant protein 1 within the bovine corpus luteum: evidence of immune cell-endothelial cell interactions in a coculture system. Biology of Reproduction $\mathbf{7 2}$ 1169-1176.

Marelli-Berg FM, Hargreaves RE, Carmichael P, Dorling A, Lombardi G \& Lechler RI 1996 Major histocompatibility complex class II-expressing endothelial cells induce allospecific nonresponsiveness in naive $T$ cells. Journal of Experimental Medicine 183 1603-1612.

Marelli-Berg FM, Frasca L, Weng L, Lombardi G \& Lechler RI 1999 Antigen recognition influences transendothelial migration of $\mathrm{CD} 4^{+} \mathrm{T}$ cells. Journal of Immunology 162 696-703.

Nagaosa K, Shiratsuchi A \& Nakanishi Y 2002 Determination of cell type specificity and estrous cycle dependency of monocyte chemoattractant protein-1 expression in corpora lutea of normally cycling rats in relation to apoptosis and monocyte/macrophage accumulation. Biology of Reproduction 67 1502-1508.

Ness JM \& Kasson BG 1995 Stimulation of rat granulosa cell progesterone production but not other differentiated functions by a splenocyte-derived factor. Journal of Reproduction and Fertility $\mathbf{1 0 5}$ 125-133.

Neuvians TP, Schams D, Berisha B \& Pfaffl MW 2004 Involvement of pro-inflammatory cytokines, mediators of inflammation, and basic fibroblast growth factor in prostaglandin $\mathrm{F}_{2 \alpha}$-induced luteolysis in bovine corpus luteum. Biology of Reproduction 70 473-480.
Nishimura R, Bowolaksono A, Acosta TJ, Murakami S, Piotrowska K, Skarzynski DJ \& Okuda K 2004 Possible role of interleukin-1 in the regulation of bovine corpus luteum throughout the luteal phase. Biology of Reproduction 71 1688-1693.

Nothnick WB \& Pate JL 1990 Interleukin-1 beta is a potent stimulator of prostaglandin synthesis in bovine luteal cells. Biology of Reproduction 43 898-903.

Okuda K, Sakumoto R, Uenoyama Y, Berisha B, Miyamoto A \& Schams D 1999 Tumor necrosis factor alpha receptors in microvascular endothelial cells from bovine corpus luteum. Biology of Reproduction 61 1017-1022.

O'Shea JD, Rodegers RJ \& D'Occhio MJ 1989 Cellular composition of the cyclic corpus luteum of the cow. Journal of Reproduction and Fertility 85 483-487.

Pate JL 1995 Involvement of immune cells in regulation of ovarian function. Journal of Reproduction and Fertility 49 365-377.

Pate JL \& Condon WA 1982 Effects of serum and lipoproteins on steroidogenesis in cultured bovine luteal cells. Molecular and Cellular Endocrinology 28 551-562.

Pate JL \& Keyes PL 2001 Immune cells in the corpus luteum: friends or foes? Reproduction 122 665-676.

Penny LA, Armstrong D, Bramley TA, Webb R, Collins RA \& Watson ED 1999 Immune cells and cytokine production in the bovine corpus luteum throughout the oestrous cycle and after induced luteolysis. Journal of Reproduction and Fertility 115 87-96.

Petroff M, Coggeshall KM, Jones LS \& Pate JL 1997 Bovine luteal cells elicit major histocompatibility complex class II-dependent T-cell proliferation. Biology of Reproduction 57 887-893.

Petroff MG, Petroff BK \& Pate JL 1999 Expression of cytokine messenger ribonucleic acids in the bovine corpus luteum. Endocrinology 140 1018-1021.

Petroff MG, Petroff BK \& Pate JL 2001 Mechanisms of cytokine-induced death of cultured bovine luteal cells. Reproduction 121 753-760.

Pober JS 1999 Immunobiology of human vascular endothelium. Immunologic Research 19 225-232.

Pober JS, Kluger MS \& Schechner JS 2001 Human endothelial cell presentation of antigen and the homing of memory/effector T cells to skin. Annals of the New York Academy of Sciences 941 12-25.

Pru JK, Lynch MP, Davis JS \& Rueda BR 2003 Signaling mechanisms in tumor necrosis factor alpha-induced death of microvascular endothelial cells of the corpus luteum. Reproductive Biology and Endocrinology 117.

Rock KL \& Shen L 2005 Cross-presentation: underlying mechanisms and role in immune surveillance. Immunological Reviews 207 166-183.

Rohn WM, Lee YJ \& Benveniste EN 1996 Regulation of class II MHC expression. Critical Reviews in Immunology 16 311-330.

Sakumoto R, Berisha B, Kawate N, Schams D \& Okuda K 2000 Tumor necrosis factor- $\alpha$ and its receptor in bovine corpus luteum throughout the estrous cycle. Biology of Reproduction 62 192-199.

Sakumoto R, Komatsu T, Kasuya E, Saito T \& Okuda K 2006 Expression of mRNAs for interleukin-4, interleukin- 6 and their receptors in porcine corpus luteum during the estrous cycle. Domestic Animal Endocrinology 31 246-257.

Scholl PR \& Geha RS 1994 MHC class II signaling in B-cell activation. Immunology Today 15 418-422.

Sen A, Wright M, Inskeep EK \& Flores JA 2006 Participation of specific PKC isozymes in the inhibitory effect of ET-1 on progesterone accumulation in cells isolated from early- and mid-phase corpora lutea. Domestic Animal Endocrinology 31 284-299.

Stewart RJ, Kashour TS \& Marsden PA 1996 Vascular endothelial platelet endothelial adhesion molecule-1 (PECAM-1) expression is decreased by TNF- $\alpha$ and IFN- $\gamma$. Evidence for cytokine-induced destabilization of messenger ribonucleic acid transcripts in bovine endothelial cells. Journal of Immunology 156 1221-1228.

Sugino N, Telleria CM \& Gibori G 1998 Differential regulation of copper-zinc superoxide dismutase and manganese superoxide 
dismutase in the rat corpus luteum: induction of manganese superoxide dismutase messenger ribonucleic acid by inflammatory cytokines. Biology of Reproduction 59 208-215.

Telleria CM, Ou J, Sugino N, Ferguson S \& Gibori G 1998 The expression of interleukin- 6 in the pregnant rat corpus luteum and its regulation by progesterone and glucocorticoid. Endocrinology 139 3597-3605.

Tokita D, Shishida M, Ohdan H, Onoe T, Hara H, Tanaka Y, Ishiyama K, Mitsuta H, Ide K, Arihiro K \& Asahara T 2006 Liver sinusoidal endothelial cells that endocytose allogeneic cells suppress $\mathrm{T}$ cells with indirect allospecificity. Journal of Immunology 177 3615-3624.

Townson DH \& Pate JL 1994 Regulation of prostaglandin synthesis by interleukin-1 beta in cultured bovine luteal cells. Biology of Reproduction 51 480-485.

Townson DH \& Pate JL 1996 Mechanism of action of TNF- $\alpha$-stimulated prostaglandin production in cultured bovine luteal cells. Prostaglandins 52 361-373.
Townson DH, O'Connor CL \& Pru JK 2002 Expression of monocyte chemoattractant protein-1 and distribution of immune cell populations in the bovine corpus luteum throughout the estrous cycle. Biology of Reproduction 66 361-366.

Turesson C 2004 Endothelial expression of MHC class II molecules in autoimmune disease. Current Pharmaceutical Design 10 129-143.

Winau F, Hegasy G, Weiskirchen R, Weber S, Cassan C, Sieling PA, Modlin RL, Liblau RS, Gressner AM \& Kaufmann SHE 2007 ITO cells are liver-resident antigen-presenting cells for activating $T$ cell responses. Immunity 26 117-129.

Young JE, Friedman CI \& Danforth DR 1997 Interleukin-1 $\beta$ modulates prostaglandin and progesterone production by primate luteal cells in vitro. Biology of Reproduction 56 663-667.

Received 11 December 2006

First decision 15 January 2007

Accepted 22 February 2007 